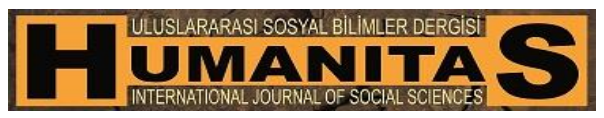

\author{
Humanitas, 2017; 5(10): 111-141 \\ ISSN: 2147-088X \\ http://humanitas.nku.edu.tr \\ DOI: $\underline{10.20304 / \text { humanitas.340639 }}$
}

Araştırma-İnceleme

\title{
AN ATTEMPT TO ESTABLISH A BILDUNGSROMAN DEVELOPMENT HISTORY: NURTURING THE RISE OF A SUBGENRE FROM ANCIENT BEGINNINGS TO ROMANTICISM
}

\section{Petru GOLBAN ${ }^{1}$}

\begin{abstract}
In English literature, the Bildungsroman, or the novel of formation, emerged as one of the most popular literary types of fiction among Victorian realists and many of the most important works of realism are Bildungsromane. But the Bildungsroman did not emerge suddenly on literary scene in the Victorian Age. The present study relies on the assumption, supported by Bakhtin, that the Bildungsroman has its own history of development as a distinct category, form, type, or subgenre of the novelistic genre, which is in itself a long, complex, and interesting process of rise and consolidation of a literary pattern, tradition, and literary system. This process can be summarized as follows: from the ancient epic and novel to medieval romances to Renaissance picaresque fiction (continued in the seventeenth century) to (in English literature) the eighteenth-century rise of the English novel with its strong picaresque substratum and through romanticism and Goethe (accredited with having introduced in fiction the element of Bildung) to the Victorian flourishing of the novel of formation following Carlyle's moment of a threefold literary reception of Wilhelm Meisters Lehrjahre. These are the main conventions which nurture the rise of the Bildungsroman as a subgenre from ancient beginnings to romanticism. Among the primary influences on the rise of the Bildungsroman, some belong, like romantic writings and Goethe's canonical Bildungsroman, to the level of "allusion". Others, like picaresque tradition and certain eighteenth-century English novels, belong to the level of "intertextuality". The present article aims to disclose by its comparative and thematological perspectives of approach a number of experiences and aspects of literary practice whose diachronic unfolding should be considered in a study on the development history of the Bildungsroman.
\end{abstract}

Keywords: Fiction, Bildungsroman, Literary System, Picaresque Pattern, The Rise of The English Novel, Romanticism, Goethe.

\footnotetext{
${ }^{1}$ Doç. Dr., Namık Kemail Üniversitesi, Fen Edebiyat Fakültesi, İngiliz Dili ve Edebiyatı Bölümü. pgolban@nku.edu.tr
} 
Golban, P. (2017). An Attempt to Establish a Bildungsroman Development History: Nurturing The Rise of a Subgenre From Ancient Beginnings to Romanticism. Humanitas, 5(10), 111-141

\section{BILDUNGSROMANIN TARİHSEL GELISŞIMIINE BİR BAKIŞ: ANTİK DÖNEMDEN ROMANTIKK DÖNEME BILDUNGSROMAN ALT TÜRÜNÜN ORTAYA ÇIKIŞI}

Öz: İngiliz edebiyatında Bildungsroman olarak adlandırılan gelişim romanı, Viktorya Dönemi gerçekçi yazarları arasında en popüler edebi türlerden birisi olarak ortaya çıkar ve o dönemde yazılan birçok gerçekçi eseri etkiler. Ancak, Bildungsroman, Viktorya Dönemi edebiyat sahnesinde birdenbire ortaya çıkmaz, tarihsel süreç içinde gelişme kaydederek şekillenir. Bu çalışma, Bakhtin'in de vurguladığı gibi, Bildungsroman geleneğinin bir roman türü olarak farklı bir gelişim tarihine sahip olduğu, kendi içerisinde uzun, karmaşı ve ilginç bir gelenek ve edebi sistem haline geldiği varsayımına dayanır. Buna göre Bildungsroman Antik dönem destan ve romanlarından başlayarak, ortaçağ şövalye romanı, Rönesans sanat anlayışı, 17. ve 18. yüzyıl pikaresk roman türünden etkilenmiş, 18. yüzyıl İngiliz romanı ve romantizmden geçerek Goethe'nin Wilhelm Meisters Lehrjahre adlı eserindeki gelişmişlik düzeyine erişir. Bildung kavramını Goethe dünyaya tanıtırken Carlyle, Wilhelm Meisters Lehrjahre'i İngilizceye çevirerek ve onu yorumlayarak kendi Bildungsromanı olan Sartor Resartus'u kaleme alır. Tüm bunlar Bildungsroman geleneğinin bir alt tür olarak ortaya çıkmasına ve gelişmesine katkı verir. Bildungsroman'ın gelişiminde öncelikli olarak "kinaye" düzleminde pikaresk roman, "metinlerarasılık" düzeyinde ise bazı 18 . Yüzyıl romanları etkilidir. $\mathrm{Bu}$ makale, Bildungsromanın tarihsel gelişimini karşılaştırmalı ve tematik yaklaşımları temel alarak incelemeyi, farklı edebiyatçıların görüşleri doğrultusunda örneklerle ortaya koymayı amaçlamaktadır.

Anahtar Sözcükler: Kurgu, Bildungsroman, Edebi Sistem, Pikaresk Roman, İngiliz Romanının Ortaya Çıkışı, Romantizm, Goethe.

\section{Introduction}

It is a critical cliché to name Johann Wolfgang von Goethe's Wilhelm Meisters Lehrjahre (1795-1796) the first Bildungsroman in world literature. Despite being seen as solely of German origins, and, by traditional Germanists, as ascribed only to this national literature and representing a unique, typical German cultural identity, the Bildungsroman, or the novel of formation, has certainly developed to the present day as an international and multi-national novelistic category, extremely rich and complex within the English-language literary production in Britain as well as America, Canada, and Australia. Our interest in the Bildungsroman is provided by the remarkable amount of interpretative attention given in our period to the analysis of the novel-writing tradition, in general, and of the Bildungsroman, in particular, which is being continually re-evaluated according to older but still valid, or more recent, or even newly emerging experiences in literary theory and criticism.

The Bildungsroman is perhaps the first type of novel allowing the hero or the heroine to speak, to show his or her individualized, subjective personality, to 
Golban, P. (2017). An Attempt to Establish a Bildungsroman Development History: Nurturing The Rise of a Subgenre From Ancient Beginnings to Romanticism. Humanitas, 5(10), 111-141

express a personal world-view, and to promote individual values against or as an alternative to some social and moral values, or some more general, eternal, and objective truths. The Bildungsroman proclaims and foregrounds the individual and individuality, and reveals the psychological and emotional complexity and spiritual insight of the human being, who is capable to change and acquire a distinct identity, to emerge, become, and complete formation.

The Bildungsroman creates complex portrayals of individuals and not symbols or ideals, not social or moral types, although in realism, other, secondary characters may be so, as well as flat and static, unlike the round and dynamic protagonist, who is an individual subject with feelings, thoughts, memories, dreams, a whole of a consciousness in progress, growth, and, above all, capable of change. However, it is wrong to consider such an approach as egocentric or individualistic, or as promoting loneliness and isolation, since most of the Bildungsromane value inter-human relationship and inter-personal dependence, and many of them also value social determinism.

The Bildungsroman entered English literature through the efforts of Thomas Carlyle and flourished as a distinct novelistic subgenre in Victorian Age, being popular especially among the realists. The Victorian writers focusing on the relationship between the individual and society and on the principle of determinism apparently found in the Bildungsroman's concern with the process of development and formation of a character the most congenial way to treat and encompass their subjects in the complexity and large scale openings of a life experience as offered by the Bildungsroman.

Just as earlier Coleridge spread German aesthetic doctrine and idealist metaphysics in England, Carlyle, in his attempts at "Germanizing" English culture in the 1830s, promotes Goethe as an authority. His efforts successfully introduce Goethe's novel and subsequently domesticate the Bildungsroman subgenre in English literature. This recruitment of a foreign literary experience should be viewed from a threefold perspective of literary reception comprising translation, criticism, and original literary work: "If Goethe's Wilhelm Meister was the main medium for spreading the ideal of Bildung among Germans, Carlyle's articles on and translations from Goethe, as well as his own version of the Bildungsroman, Sartor Resartus, were the most influential in introducing the concept to England" (Argyle, 2002: 24).

In general, it is considered that the Bildungsroman was founded by Goethe with Wilhelm Meisters Lehrjahre as the prototype of the form (since this novel marked the use of the principle of Bildung, formation, or as for Bakhtin, becoming, in matters of character representation strategies), and that the Bildungsroman (the novel of formation) flourished in English literature in the Victorian Age among the realists. 
Golban, P. (2017). An Attempt to Establish a Bildungsroman Development History: Nurturing The Rise of a Subgenre From Ancient Beginnings to Romanticism. Humanitas, 5(10), 111-141

\section{The Bildungsroman and Its Predecessors}

Not only among the realists in the Victorian period, we should add, and it also continued in the age of modernism in the first half of the twentieth century as both modernist and realist, and also in the postmodern period to the present displaying a larger and a more remarkable typology.

And we should also add that the rise of the Bildungsroman did not owe solely to the Germans and Goethe. Rather, the rise of the Bildungsroman is a long and complex process, of a larger literary and continental resonance, with antecedents in antiquity and the medieval period. With regard to the English Bildungsroman, it enjoyed a significant contribution from the picaresque tradition and the rise of the English novel in the eighteenth century (with their verisimilitude, moral didacticism, social concern, and so on), and, last but not least, romantic literary practice (with its emphasis on individual experience, focus on nature, concern with the experience of childhood, the dualism of existence, and other thematising strategies). Finally, following Carlyle's moment of a threefold literary reception of Goethe's canonical Bildungsroman, this moment led to finding a way in which to produce a literary discourse that offers a particular modality concerning the figure of the main hero/heroine as being constructed in the novel, where in the Bildungsroman it constitutes the image of the individual subject in the process of becoming, growth, development, whose essence is the principle of identity formation.

Bakhtin would show and argue in his "The Bildungsroman and Its Significance in the History of Realism: Toward a Historical Typology of the Novel" (19361938) that the Bildungsroman, like with the novel in general, passes through its own diachronic process of development in which certain thematic and structural elements occurred historically to survive, develop, disappear, change including their status as centre and margin - in order to establish the literary system of the novel of formation as a distinct type or subgenre of the novelistic genre.

A study on the development history of the Bildungsroman would focus on particular texts, such as picaresque works, Tom Jones, The Prelude, and, necessarily, Wilhelm Meisters Lehrjahre, in order to disclose aspects of thematic arrangement that are later detected as elements of the Bildungsroman literary system.

Such an approach assumes the validity of the theory of internal change in literary advancement through history and shows that the Bildungsroman emerges as a literary system of certain common, typical and defining thematic and structural elements as a result of a historical developmental experience during which various aspects, in particular thematic, of different periods, movements and genres, survived, changed and interrelated anew - and continue to do so - in their acts of narrativization within the system of the Bildungsroman. In this way, these aspects disclose the essential hybridity of the 
Golban, P. (2017). An Attempt to Establish a Bildungsroman Development History: Nurturing The Rise of a Subgenre From Ancient Beginnings to Romanticism. Humanitas, 5(10), 111-141

Bildungsroman novelistic subgenre, whose central element is identity formation.

Indeed, the antecedents of the Bildungsroman are many and of an extensive temporality starting with antiquity to the eighteenth century. Bakhtin and other critics made remarkable attempts to identify them in their studies on the Bildungsroman; they mostly emphasize Goethe, but also find intertextual relations to such traditions as allegory, picaresque fiction, and the romance, which are among the most important "non-Goethean prototypes for the Bildungsroman", ranging from

the Bunyanesque hero looking for salvation through a world peopled with allegorical representations of virtue and vice, to the picaresque hero whose adventures take him instructively through various strata of society, to the quester like Parsifal, who learns through painful experience how to reach his goal, and what his goal is worth. (Jeffers, 2005: 61)

Following Bakhtin's classifications and arguments, which are foundational to any research on fiction, and relying on the assumption that the Bildungsroman, as literature in general, is a system of certain defining elements that emerged and established diachronically, we may identify, by focusing on literary periods, movements, trends, genres, subgenres, particular writers and texts, what we believe are the most important antecedents of the Bildungsroman.

In this respect, apart from a number of ancient and medieval sources, we may talk about five major modern precursors of the English Bildungsroman, its main sources of origin and influence: (1) picaresque narrative, (2) the rise of the English novel in the eighteenth century, (3) romanticism, (4) Goethe's Wilhelm Meisters Lehrjahre, and (5) realism.

The Bildungsroman in its historical movement, at least in its English version, can be viewed as part of a larger, generic system, of the novel, or of literature, in general, in which it represents at once the culmination of a developmental process and the starting point for a complex novelistic typology, which, to the present day, still develops and diversifies its system of elements.

With antecedents in ancient and medieval periods, and influenced by picaresque fiction, the rise of the eighteenth-century novel, the romantic aesthetic and literary practice, and Goethe's prototypical work, the Bildungsroman in English literature emerged in the nineteenth century from the context of romanticism and established as a novelistic pattern and tradition systematized by realism. The pattern is built upon the principle of Bildung (formation, becoming, or emergence), which acquires the central, dominant position in the newly developed literacy system. Formation is linked to the reconfiguration of the entire spiritual spectrum, the world of inner existence; it became central in romanticism paving the way for Goethe through the romantic emphasis on individual emotional and psychological experience. But Goethe also relies on an 
Golban, P. (2017). An Attempt to Establish a Bildungsroman Development History: Nurturing The Rise of a Subgenre From Ancient Beginnings to Romanticism. Humanitas, 5(10), 111-141

idealist tradition of the Enlightenment, which stipulates an organic and gradual growth leading to both individual fulfilment and social integration. This aspect of individuality in the process of identity formation remains essential and defining to the present, including in the realist type of the Bildungsroman, and the Victorian authors (also, to an extent, originating in Goethe) added the component of the acquiring of meaningful existence in society, where the individual development often clashes against a cruel milieu and the social integration is possible only by compromise.

This classification takes for granted the existence of a typical English Bildungsroman, and shows that it has been highly prolific, it is still very much alive, not only in Great Britain and in English-language literature. In the field of literary theory and criticism, the Bildungsroman studies should dismiss the critical cliché claiming that the Bildungsroman declined or even died with modernism; instead, one should take into account the nation, culture, and genre as distinguishing features and differences among novels, since the Bildungsroman is internationally widespread (West as well as Africa, Asia, Latin America) and popular with various types of minority writers, and especially responsive to different older and newly emerging theories, ideas, means of artistic expression, and literary and novelistic experiences (such as psychoanalysis, feminism, post-colonialism, magical realism, metafiction, historiographic metafiction, dystopia, simulacrum, posthuman, and others), which provide emerges with Goethe as a distinct subgenre of the novel genre largely as a modified, different, and more advanced, we should claim, version of picaresque fiction. This version occurs owing to the contribution of preromanticism and romanticism, in particular the romantic concern with individual experience and the romantic expression of the dualism of existence, escapism, rebelliousness, and, on the whole, of various emotional and psychological states.

Our view of the Bildungsroman having roots in antiquity and as a superior, more advanced novelistic form of the picaresque combined with various romantic perspectives materializes itself in our work from assuming the hypothesis that to follow the rise, development, and consolidation of the Bildungsroman fictional pattern is to follow, according to Bakhtin, the historical movement of the novelistic prose, in general, and, in particular, the ways in which the image of the main hero is constructed (formulated) diachronically in the novel. On the whole, there is this critical cliché stating that the novel as a literary fact appeared in the ancient period, but the modern novel appeared in the Renaissance as a counterpoint to the ancient epic and the medieval romance, as a parodic play with their forms and concerns, which is remarkably argued, among others, in his diachronic approach to the novelistic genre, by Erich Auerbach in Mimesis.

\section{Bakhtin on the Bildungsroman and Other Fictional Types}


Golban, P. (2017). An Attempt to Establish a Bildungsroman Development History: Nurturing The Rise of a Subgenre From Ancient Beginnings to Romanticism. Humanitas, 5(10), 111-141

According to M. M. Bakhtin in "The Bildungsroman and Its Significance in the History of Realism: Toward a Historical Typology of the Novel", there are four types or subcategories of novel dealing with the life experience of the fictional hero or heroine: (1) the "travel novel", (2) the "novel of ordeal", (3) the "biographical novel", and (4) the Bildungsroman. The first three types have a longer history of development starting with the ancient period, whereas the Bildungsroman emerges on the literary scene at the end of the eighteenth century. However, all four of them are interrelated by having in common thematic elements such as biography, life-time period, ordeal, travel, adventure, love, place in human community, and others.

For us, the travel novel, the novel of ordeal, and the biographical novel constitute the development of the novelistic genre from antiquity in the form of a process during which, at the beginning of modernity, occurs the moment of the rise of the literary system of the picaresque narrative, which - along with the previous types of novel, certain romantic thematic aspects, the eighteenthcentury English novel, and, finally, Goethe's Wilhelm Meisters Lehrjahre provides the main elements for the rise of a new literary system, which is that of the Bildungsroman.

Plainly stated, the history of the development of the Bildungsroman in English literature represents a process from (1) the ancient epic and novels to (2) medieval romances to (3) Renaissance and later picaresque fiction to (4) the eighteenth-century neoclassicism and the rise of the English novel and (5) romanticism through (6) Goethe and Carlyle, and the influence of (7) realism to the Victorian novel of formation.

What differentiates the Bildungsroman from other types is the element of formation, which stands as the centre, the main thematic element in the literary system of the Bildungsroman. Formation, for us, or Bildung, in general, or becoming and emergence (stanovlenia), for Bakhtin, provides the main feature, specificity, and essential nature of the Bildungsroman. In other words, the element of formation makes Bildungsroman that type of fiction which deals with the "the image of man in the process of becoming" (Bakhtin, "The Bildungsroman" 19).

Also, we could say that the travel novel, the novel of ordeal, and the biographical novel are different fictional hypostases of the developmental novel (or the novel of development) distinguished from the Bildungsroman as the novel of formation, that is, Entwicklung different form Bildung, or Entwicklungsroman, as Germanists would say, different from Bildungsroman.

The physical aspect of experience aside, concerning thematization of the psychological aspect, spiritual life, and inner dimensions of experience, the travel novel, the novel of ordeal, and the biographical novel have as the key word with regard to character representation the term static, whereas for the Bildungsroman the key word would be change of the inner perspectives of 
Golban, P. (2017). An Attempt to Establish a Bildungsroman Development History: Nurturing The Rise of a Subgenre From Ancient Beginnings to Romanticism. Humanitas, 5(10), 111-141

existence (psychological, emotional, and moral), which leads to formation, emergence, becoming of the personality of an individual subject.

The Bildungsroman as a particular subgenre, literary tradition and literary system emerged when identity development became a literary concern and character started to be presented - or his/her image in the novel to be constructed - in the process of becoming (in Bakhtin's formulation), emergence, change, that is, what we call, Bildung or formation of character, that is, acquiring of identity, which replaced the static and fixed, ready-made features of the human subject, and to which the thematic perspective of rendering the biological and intellectual growth and development of personality from childhood through adolescence and youth to maturity was added. Change is a major premise for achieving identity formation, where change and identity, along with "freedom and happiness", "security and metamorphosis", are "all equally important for modern Western mentality" (Moretti, 2000: 9), among whose aesthetic products is the Bildungsroman.

Another assumption, which we rely on, and which follows the formalist theory of system and internal change, is that the rise and advancement of fiction writing from the ancient period to the end of the eighteenth century encompass a number of principles, devices, and elements of the literary discourse which developed and changed diachronically in the history of novel writing so as to eventually offer to the Bildungsroman a number of narrative and thematic aspects by which to prove the aesthetic validity and continuity of a literary tradition.

According to Bakhtin in "The Bildungsroman", these elements and aspects construct or formulate, already in the ancient classical period, the image of the hero in literature; among them, although mostly always offering a static, abstract, and idealized image, are those of realism, spatial and social diversity, complexity and diversity of the external world, complexity and unity of the image of man, inner life and psychology, biographical course of life, adventure spirit, ordeal, testing of virtues, crisis, spiritual rebirth, and, to a certain extent, change of some spiritual components.

These elements, aspects and categories are all of primary importance when describing the rise and development of the literary pattern of the Bildungsroman, since they represent elements of the Bildungsroman literary system that established in the eighteenth century and flourished in the nineteenth century. What is primarily involved in our interpretative strategy is the image of the character (main character, hero or heroine, protagonist) presented in the process of development (of identity) leading to formation (of identity) according to the principle of chronotope, and to this element of formation all other aspects and elements are to a greater or lesser degree subordinate. Chronos and topos, time and place, play a significant role as counterparts of one single mechanism of literary approach to the development 
Golban, P. (2017). An Attempt to Establish a Bildungsroman Development History: Nurturing The Rise of a Subgenre From Ancient Beginnings to Romanticism. Humanitas, 5(10), 111-141

of the Bildungsroman, in general, and of the image of its protagonist, in particular, from antiquity through picaresque fiction, the eighteenth-century rise of the English novel, romanticism and Goethe to the Victorian Bildungsroman. In Bakhtin, chronotope is of several types, and concerning literature:

In the literary artistic chronotope, spatial and temporal indicators are fused into one carefully thought-out, concrete whole. Time, as it were, thickens, takes on flesh, becomes artistically visible; likewise, space becomes charged and responsive to the movements of time, plot and history. This intersection of axes and fusion of indicators characterizes the artistic chronotope. (Bakhtin, "Forms of Time", 1981: 84)

In Bakhtin, "chronotope" - the name (literally, "time space") being given to "the intrinsic connectedness of temporal and spatial relationships that are artistically expressed in literature" - is a key-element in his theoretical framework on genre (an important organ of memory and no less important vehicle of historicity) and in particular in his theory of the novel.

\section{First Elements in Antiquity and the Middle Ages}

Fiction in its incipient form in antiquity already provides some clearly marked types of the novel (the travel novel, the novel of ordeal, and the biographical novel), their elements being in a state of interdependence and reciprocity, and characterizing one or another principle of character developmental process. Diachronically these principles change as does the novel itself in its general historical and cultural development, just as they mark the importance and dominance of one upon the other. Among ancient literary complexity, the closest to the modern idea of Bildung, or formation, is Apuleius's The Golden Ass (Metamorphoses). The protagonist Lucius is thirsty for knowledge and news, and, leaving his homeland to learn magic, his adventure ends in a "final dissociation between essence and appearance" (Roznoveanu, 1983: 317); he acquires a personal identity, almost similar to that of a Bildungsroman character, at the end of a process leading from instinct to idea and reason, and instead of magic and witchcraft he eventually discovers philosophy.

Concerning the next period in the movement of literature, the Middle Ages, and the contribution of the medieval romance to the Bildungsroman development history - even if it appears at first that the romance represents a series of incredible adventures constructed on trite formulas - this narrative tradition nourished the spirit of adventure, promoted initiation and a sense of ordeal, trial, testing of human moral potential. The romance strengthens some and offers other elements to the system of the Bildungsroman despite the characters not being presented in their general growth or as changing while gaining experience (they are, as in antiquity, mainly static), and despite an attempt at escape from reality, or the idealization of it, which represents, along with moral didacticism, another chief value desired by the authors of romances. 
Golban, P. (2017). An Attempt to Establish a Bildungsroman Development History: Nurturing The Rise of a Subgenre From Ancient Beginnings to Romanticism. Humanitas, 5(10), 111-141

In particular, ordeal or test will become a central element in the Bildungsroman literary system. In the Bildungsroman, there are various types of tests, which are initiatory and crucial for the acquiring of identity formation. The first one is related to the sentimental career, a kind of "sexual test", in which the protagonist moves beyond the family background and "finds someone else - an appropriate partner outside the family - to love"; the second is related to the professional career, a "vocational test", more common in the realist Bildungsroman, in which the protagonist "must find a way relating himself not just to someone but to everyone in the society at large"; the third is a type of individual test, more specific to the Künstlerroman dealing with the maturation of the artist or to modernist novels, which is "that business of ruminating, but especially about the connections between art, ethics, and metaphysics, the practical stress falling on the middle term" (Jeffers, 2005: 64). In all cases, the protagonist of the Bildungsroman goes through several vocational perspectives, and through at least two love affairs, and changes artistic projects in order to find the right one and to become aware of the kind of existence and philosophy of life that are the most appropriate to his individuality.

\section{The Contribution of the Picaresque Fiction in Renaissance and Later Periods}

In the Renaissance, responsible for the transition from the romance to the novel (roman) are Cervantes and the writers of picaresque fiction. As a modern form of writing, the novel is a "parvenu" that achieved considerable success in a short time at the expense of the conquered and exploited territories of its neighbouring genres - drama, essay, story, epic, romance, apology, chronicle, biography, and so on - territories that it patiently absorbed until transforming the whole literary domain into a colony (Robert, 1983: 48). The novel dominates to the present the literary life modified by its aesthetics and depending on its consumerist success.

The romance becomes roman as verse is replaced with prose, and especially as the fantastic element is replaced with verisimilitude (the realist element), generously privileged by both literature and reality, and, as a consequence acquiring unlimited and absolute freedom of expression. This principles of freedom and of absence of the fantastic element and its substitution by verisimilitude, necessary to the existence of the novel, brought changes and diversification on both structural and thematic level from the romance and other genres to the novel. Concerning themes and plot, and in the context of the rise of the English novel in the eighteenth century, it meant, as shown by Fielding in his novels and his "Preface" to Joseph Andrews, an extended social concern, focus on individual experience, a large circle of incidents, characters from different backgrounds, and so on. Among the aspects of transition and as an essential difference between the romance and the novel is the element of characterization, which is also important for our surveyistic approach to the 
Golban, P. (2017). An Attempt to Establish a Bildungsroman Development History: Nurturing The Rise of a Subgenre From Ancient Beginnings to Romanticism. Humanitas, 5(10), 111-141

Bildungsroman development history. The most concise remark on this matter belongs to Northrop Frye in Anatomy of Criticism: Four Essays, in which he claims that the romancer "does not attempt to create 'real people' so much as stylized figures which expand into psychological archetypes", whereas the novelist deals with personality, with characters wearing their personae or social masks" (1990: 304-305). However, we may disagree with Frye's affirmation that the romance deals with individuality and the novelist needs the framework of a stable society. The medieval romance - be it Gawain, or Chanson de Roland, or whatever chanson de geste - promotes the heroic ideal and the heroic narrative which is also a historical one, at least in its reference to real historical situations and characters with a "historical-political function", even if they are "denaturated and simplified", and with a limited representation of real life, the daily practical domain being separated from "the sublime heroic domain" (Auerbach, 2000: 110).

The novel, in turn, promotes verisimilitude, social and moral concern, and tends towards character individualization. Verisimilitude is a constituent element in the rise and consolidation of the literary system of the novel in the Renaissance in Spanish and then European literature, in general, and in the eighteenth century in English literature. Verisimilitude becomes, in the nineteenth-century fiction, the main material of thematic concern, the subject matter of the fictional discourse; the novel is here about verisimilitude and by this it establishes a new type and trend in fiction - realism and the realist novel - which can be defined, in Frye's words, as "art of verisimilitude and implicit simile".

With respect to the Bildungsroman development history, apart from the textualization of verisimilitude, the Renaissance brought new elements in the construction of the image of the protagonist to further contribute to the process of establishment of the novel of formation. Just as with the novelistic genre, the romance changing into the novel, the static character is on his or her way of being marked by change and eventually be replaced with the formation (or emergence) of character to result in the eighteenth- and nineteenth-century Bildungsroman.

Namely, the transition from the static feature of the character towards the principle of development and through it eventually to that of formation is provided by the picaresque novel, one of the first and most important types of fiction. Like the Bildungsroman, the picaresque novel reveals continuity and vitality to the present due to its being established since the sixteenth century as a definable system with particular features/elements, and, like the Bildungsroman, due to its being "capable of regenerating and transforming itself in a surprising variety of new environments" (Alter, 1965: ix). The elements of the picaresque novel, which form its thematic pattern, include

(1) the chronotope of the road; 
Golban, P. (2017). An Attempt to Establish a Bildungsroman Development History: Nurturing The Rise of a Subgenre From Ancient Beginnings to Romanticism. Humanitas, 5(10), 111-141

(2) inconsistency of the protagonist (picaro(a)) of low social standing, but of a vast typology of roles and individual traits: orphan, servant, delinquent, beggar, trickster, and so on; typically a "nomad", a "rolling-stone", rootless, homeless, social rebel, radical, escapist, sometimes ending his revolt in compromise;

(3) "pseudo-autobiographical perspective", in Richard Bjornson's terms;

(4) "panorama of representative types", again Bjornson with regard to the literary convention of realism and its social concern;

(5) moral didacticism, since the story conveys a message to the reading public of middle class and "literate people from the lower classes" (Bjornson, 1977: 206);

(6) comic mode combining ironic attitude and social satire, the picaro(a) observing and disclosing without any prejudices the social and human frailties and hypocrisies;

(7) twofold perspective of self-fulfilment reified by a double change: (1) social advancement/climbing (development towards social accomplishment, including professional, financial, artistic, and other aspects, that is, socio-economic change of the individual's external condition) and (2) spiritual gain (development towards maturity (intellectual, psychological, emotional, as well as physical) and acquiring of the self through struggle with a hostile and chaotic world, and especially through spiritual suffering, trial and repentance, that is, moral-religious change of the individual's inner condition).

Like Guillén's eight characteristics (in "Toward a Definition of the Picaresque", 1971: 71-89), our seven features are essential but not invariable; they are indispensable to understanding the development of the picaresque as a subgenre, in particular, and of the novelistic genre, in general, but they do not encompass a strict formula. Like Guillén, we accept exceptions and secondary characteristics, and consider that no single picaresque novel embodies completely all these seven features; the subgenre has been and still is flexible and subject to development, change, thematic and structural enrichment. To qualify as picaresque, a novel must contain the majority of them; otherwise, the presence of pseudo-autobiographical form, or of moral didacticism, for instance, does not automatically make it a picaresque text.

These seven features, emerging in different literary periods, trends, genres, and textual typology, modified and accompanied by various other secondary features, are essential to provide a conclusive definition to the picaresque subgenre of the novel and to make picaresque a universal narrative type, which leads to its classification as "picaresque myth" born from within a socio-cultural context and marking the rise of the novel as a distinct genre, which, in its incipient stage, combines literature with history, especially law, and other discourses. 
Golban, P. (2017). An Attempt to Establish a Bildungsroman Development History: Nurturing The Rise of a Subgenre From Ancient Beginnings to Romanticism. Humanitas, 5(10), 111-141

In this respect, it is revelatory to disclose the meaning of the term used to label the protagonist. The noun giving the adjective - picaro $(a)$ - is used in most cases, whose main synonyms in critical discourse are vagabond and delinquent, and most often rogue, but there are critics, such as Claudio Guillén, who make a clear distinction between picaro and rogue: first, the former is exponential only to the genre of the picaresque novel, whereas the latter appears in various genres and under different guises; second, more important, the former lacks the connotation of delinquency, as compared to rogue:

The picaro is an occasional delinquent. The tendency to criminal behavior is not an in-bred feature of his character. His allergy to work, his spirit of defiance lead him to use crafty, half-dishonest methods of the parasite. If he steals, he is driven by necessity and more sinned against than sinning. (Guillén, The Anatomies of Roguery, 1987: 138-9)

Action, adventure, travel, trial, interaction with the external world dominate the picaresque narrative, in which "the self is frequently depicted in the traditional manner as an inherent 'nature' which is tested and revealed for what it is during the course of the hero's fictional adventures" (Bjornson, 1977: 11).

The picaro/picara in his/her double hypostasis as character and narrator provides, on the one hand, unorthodox, satirical attitudes towards social values and conventions disclosing that reality is different from what it appears to be, and, on the other hand, unorthodox, parodic attitudes towards other literary and non-literary discourses and traditions.

But the picaro(a) is naturally good, changed into a villain or delinquent by the circumstances, and breaks the law only occasionally and in order to survive rather than to question or defy it, as in the case of the picaro from Lazarillo, for instance, who steals the sausage not to take advantage of his master's blindness but not to starve. In general, the picaro(a) is solitary, outcast, alienated, as well as a fighter, never defeated, and in all cases does not see society as an enemy; his/her action is far beyond any serious criminal act, and involves disguise or trickery in order to deceive for food, or money, or a better job, or a higher social position. All or some of these are eventually granted to the picaro(a); however, on other grounds and for other reasons: containing the premise to change over and over again, s/he is granted the possibility of understanding, repentance, moral betterment, spiritual gain, and the subsequent realization of the self and eventual change of inner condition, in order to acquire a new, improved spiritual and moral status, and a new, genuine and solid philosophy of life.

These are aspects of a private experience that offers success, personal and social accomplishment, and, in another, distinct and more advanced form of thematization, becomes indispensable to the principle of formation in the Bildungsroman.

These are aspects of an existential process, which Bakhtin, in "Forms of Time and of the Chronotope in the Novel", in relation to the "adventure novel of 
Golban, P. (2017). An Attempt to Establish a Bildungsroman Development History: Nurturing The Rise of a Subgenre From Ancient Beginnings to Romanticism. Humanitas, 5(10), 111-141

everyday life", calls "the path of life" and speaks about the sequence of guilt retribution - redemption - blessedness, which could be also said to represent the experience of the picaresque hero as well as that of David Copperfield, Pip, Jane Eyre, and other protagonists of the Bildungsromane.

In this process of transformation of the static character into a dynamic one, that is, into an individual subject subjected to formation and emergence, the most important contribution was that of the picaresque novel and later romantic literary works. In the case of the former, a less sentimental literary discourse, the picaro(a), or the rogue, an anti-hero/anti-heroine - struggling for survival in a marginal situation, desiring economic individualism and a congenial social status, placed on the road, changing outer and inner condition, and acquiring an identity, a self, and a philosophy of living - is a major predecessor of the character of the Victorian Bildungsroman with regard to the thematic treatment of the relationship between the individual and milieu, and the issue of the success of formation reified by social integration and accomplishment of a socially determined subject who gains economic individualism and independence.

\section{The Romantic Impulse}

The romantic tradition, with its emphasis on individual experience, constructs a character typology that prefigures the character of the Bildungsroman pertaining to literary expression of inner thoughts and feelings, inner emotional and psychological states, the value of private life, the importance of childhood experience, the interdependence of human and nature, the concern with the dualism of existence and escapism, and the issue of the success of formation reified by personal accomplishment of an individual subject. Romanticism would come to enrich and improve the literary system of picaresque fiction by making individual, in particular subjective, experience a literary concern, which is no less inferior than society, especially the complex range of feelings, since in the picaresque narrative, in general, the hero "is oriented toward action, not feeling. In his rough world, he has neither leisure nor the interest to relish the nuances and degrees of purity of his own emotions" (Alter, 1965: 79).

In the history of literature, in general, the importance of romanticism emerges from breaking the linearity of literary development dominated by classical principles, and from reviving the spirit of originality in literature, which resulted in the co-existence of both innovative and traditional trends in the Victorian Age, the twentieth century, and the contemporary period.

In the Bildungsroman development history, the importance of romanticism is no less significant. Although Goethe is generally accredited with having introduced Bildung, making formation, or becoming, a fictional reality with regard to character representation strategies, romantics, in their literary concern with the development of an individual subject, introduced the formative principle and used it in a very similar to the Bildungsroman way of thematic representation. 
Golban, P. (2017). An Attempt to Establish a Bildungsroman Development History: Nurturing The Rise of a Subgenre From Ancient Beginnings to Romanticism. Humanitas, 5(10), 111-141

To give an example, Tintern Abbey shows an individual in his early adulthood corresponding to the moment in the Bildungsroman of the character entering upon maturity. Therefore, Wordsworth's poem can be viewed as a short protoBildungsroman in verse form, or even can be called a Bildungsgedicht or Lehrgedicht. The principle of formation here is conceived as interrelated with nature and the rural setting; nature, in particular, is the source of formation and becoming not simply of a mature personality but of a poet. In the process of development of a poetic mind from youth to maturity, concerning the formation as a poet, nature co-participates - in matters of "emotion recollected in tranquillity" - in the process of literary composition. As a result, in a kind of coauthorship, the poem is being written by the assistance of nature, which means that the poet achieves formation, and the poem deconstructs its own process of composition, the way in which it is actually being written, and hence the poem, besides being a proto-Bildungsroman, or rather Bildungsgedicht or Lehrgedicht, is also a self-reflexive poem, a metapoem.

Nature is a parental figure, a formative principle offering, to be more precise, a guided formation, which in romanticism, besides nature, could be offered by the experience of childhood, or a particular type of relationship with reality and human community. Such a guided formation is common to the Bildungsroman in general and could be of various other kinds, as in the Victorian realist Bildungsroman, for instance, in which society rather than nature is a formative principle providing a special type of guided formation, which we could call determined formation.

Nurturing the rise of the literary system of the Bildungsroman in the nineteenthcentury English literature, romanticism contributes to this process by both its fiction and poetry. Above all, the romantic contribution encapsulates its concern with personal, private, inner, individual experience and all its related thematic perspectives - including childhood, nature, rustic life, pantheism, the dualism of existence, escapism, rebelliousness, and a certain social attitude - which the Victorian writer of the novel of formation will add to those already provided by the rise of the eighteenth-century English novel: social concern, moral didacticism, picaresque elements, and others.

Some Victorian novels of formation, such as Sartor Resartus (claimed to be the first English Bildungsroman), rely heavily on these romantic aspects; others, like the more avant-garde Marius the Epicurean, reshape them; but, more often, they are incorporated to a lesser or greater extent in various realist novels, such as Jane Eyre, Great Expectations, and The Mill on the Floss.

As expressed by the romantics, childhood is the writer's co-author; nature is also involved in co-authorship; childhood and nature represent a mode of existence, just like dualism is; pantheism is related to dualism as much as escapism and, to a certain extent, rebelliousness are; and, in English romantic 
poetry, the dualism of existence is a result of creating an alternative universe to the contemporary social construction of reality.

Therefore, the concern with the growth of a poetic mind, the concern with the experience of childhood, the concern with nature and the countryside, the dualism of existence, and escapism represent aspects of the contribution of romanticism to the rise of the literary system of the Bildungsroman. A romantic social concern and whether the individual placed between escapism and rebelliousness is rendered in the context of a milieu remain important topics of critical inquiry.

Whether romantic writers are concerned or not with social issues, are involved or not in topics of actual existence, is a matter of critical debate as is, for instance, the question of whether romanticism is a fragmented or unitary movement with regard to its range of literary perspectives and theoretical approaches. The argument favouring the textualization of a romantic social concern relies on the assumption that the romantic focus on the relationship between subject and society, just like the romantic concern with nature and childhood, emerges from a particular cultural response to the beginnings of industrialization, the threat of regimentation of the individual, and the rise of our mass-society, which is perceived as obstructive. The question, however, of the ways in which individual and social life are thematized to render the relationship between the human being and society is much more complex than the above stated critical clichés, ranging from the aspects of childhood, nature, authorship and culture to those of the dualism of existence, rebelliousness, and escapism. To reveal the complexity of the thematic concern regarding the relationship between the individual and society as expressed in romantic literary works in relation to these aspects by Blake, Wordsworth, Coleridge, Keats, Shelley and Byron represents a way of identifying romantic elements in the general system of the Bildungsroman.

The starting point to achieve this desiderate would be to assume the view that all these aspects - childhood, nature, society, dualism, pantheism, escapism, rebelliousness, co-authorship - are interrelated under the auspices of the more general romantic concern with individual experience of a particular human subject. Brought together in the context of the rise of individualism in romantic culture and literature, these aspects receive their textual expression in all English romantic authors and can be found throughout the entire romantic literary practice, in particular poetic works about nature, in which nature is the chronotope of dualism, escapism, and the assertion of pantheism and authorship in romanticism.

Paralleling the relationship between the individual and nature is the relationship between the individual and society, both of these romantic concerns being disclosed by the romantic dualism of existence. 
Golban, P. (2017). An Attempt to Establish a Bildungsroman Development History: Nurturing The Rise of a Subgenre From Ancient Beginnings to Romanticism. Humanitas, 5(10), 111-141

Although the relationship between the individual and society is a literary concern commonly attributed to realist fiction that emerged in the nineteenth century succeeding to and as a reaction against romanticism, there are many critical voices who claim romanticism to be a cultural as well as a social movement with its own ideology and politics, where romantic literary works disclose a particular outlook on the contemporary French revolution, industrial revolution, the rising reactionary political attitudes and various social theories, etc. M. H. Abrams, for instance, calls romantic writers "political and social poets", and, "to a degree without parallel, even among major Victorian poets, these writers [romantics] were obsessed with the realities of their era"; therefore, it is "a peculiar injustice that romanticism is often described as a mode of escapism, an evasion of the shocking changes, violence, and ugliness attending the emergence of the modern industrial and political world" (1970: 101).

To others, romanticism is first of all a movement in arts and literature, a literary doctrine and literary practice with a strong philosophical basis developed in Germany and which established itself as a strong literary tradition, which covers all major genres, especially poetry, as well as, to various extents, fiction, drama, essay, letters, confessions, memoirs, aesthetic guidelines, and literary criticism. Such critics understand romanticism "aesthetically, as a theory about the nature and origin of art" (Butler, 1981: 8), and the identification of literature with philosophy "appears in romanticism not only in the emergence of German romanticism in response to Kant, and in the Jena romantics' conception of literature as containing its own criticism. It has been for romantics and their readers a way of describing a kind of truth value or truth effect of poetry" (Chase, 1993: 15). Romantics are those writers who "see the implication of imagination, symbol, myth and organic nature, and see it as a part of the great endeavour to overcome the split between subject and object, the self and the world, the conscious and the unconscious" (Wellek, 1963: 220).

Therefore, despite the opinion that romanticism is not a "coherent movement or period in Western literature, thought and culture - it was too contradictory, with too many forms and tensions, to be known by one name" (Bahti, 2001: 32), one would claim that romanticism is a cultural, aesthetic, and literary attitude, a unified movement, a literary system whose thematic concerns include, among others, the emphasis on imagination, feelings and inspiration, the exploration of the complex range of emotional and psychological states, the rise of individualism, the revival of national cultural heritage, the dualism of existence, escapism, rebelliousness, the concern with nature and the countryside, and the importance of childhood experience.

As some of these aspects are related to the rise of the Bildungsroman in the Victorian period, we may focus on the ways in which romantics thematized the relationship between the individual and society in order to discuss this issue in 
Golban, P. (2017). An Attempt to Establish a Bildungsroman Development History: Nurturing The Rise of a Subgenre From Ancient Beginnings to Romanticism. Humanitas, 5(10), 111-141

connection with the above mentioned thematic concerns, namely the rise of individualism and the dualism of existence, as well as escapism and rebelliousness. The starting hypothesis is that the textual representation of the romantic dualism of existence is thematically interconnected with and reveals the romantic textualization of the relationship between the individual and society, the relationship between the individual and nature, the return to the experience of childhood, and, more important to the essence of the Bildungsroman, a process of individual growth and development.

Such thematic concerns as the dualism of existence, rebelliousness, escapism, childhood, nature, and the relationship between the individual and society reveal romanticism to be a unitary movement and to emerge in the literary discourses of various writers from different cultural backgrounds, who came under the influence of romantic aesthetic theory and practice. Even from those cultural backgrounds, such as Turkish, which do not possess, like Germany or England, a clear, historically delineated, romantic period, but whose nineteenth-century literary works contain romantic elements and concerns.

Founding the literary system of the Bildungsroman, the Victorian writer of the novel of formation will keep the romantic thematic perspectives adding them to those already provided in the context of the rise of the eighteenth-century English novel. The romantic aspects would be mostly predominant in those Victorian novels of formation that keep alive the romantic tradition, as in Sartor Resartus, perhaps the first English Bildungsroman, and persist in realist, both low-mimetic and high-mimetic, novels, as in Jane Eyre, Great Expectations, and The Mill on the Floss, or be reshaped in more avant-garde, anti-realist works, as in Marius the Epicurean.

The Victorian Bildungsroman would combine the perspectives (picaresque, of the eighteenth-century novel, and romantic) and declare identity formation successful if at the end of the protagonist's process of maturation the inner and outer aspects of existence are harmoniously balanced, and personal ambitions and values agree to the requirements of social existence.

To this end, the picaresque narrative passed through a process of especially thematic transformation that occurred in the eighteenth century due to the new social and cultural circumstances, new literary forms, and, in particular in English literature, due to neoclassicism, the dominant literary doctrine of the period, which subjugated poetry and influenced the rise of the English novel in general. Tom Jones, in particular, reveals the picaresque tradition as modified and innovated in order to adapt its thematic pattern to the new cultural and social circumstances. The emphasis is "more on the ingenuity and less on the struggle" (Alter, 1965: 31), more on reflection than adventure. Also, breaking the convention of picaresque fiction, Moll Flanders is placed in a middle-class setting, but, subject to the world's and life's chaotic and obstructing circumstances, and bereaved of a stable existence, she has to struggle for 
Golban, P. (2017). An Attempt to Establish a Bildungsroman Development History: Nurturing The Rise of a Subgenre From Ancient Beginnings to Romanticism. Humanitas, 5(10), 111-141

survival in an alien world both as a picara and woman, and, like Jane Eyre, embark on a more difficult and complex process of social ascension and affirmation of an individual identity. Unconventionally, if Moll is adopted by a middle-class family, Roderick Random is born in an upper-class family, but he is likewise subject to misfortune, finding himself soon enough - after the death of his parents and being rejected by his grandfather - with no support to face the harsh conditions of social reality. Tom Jones, a foundling, is rewarded by a superior social status in a novel that reveals a fresh approach to an established novelistic tradition; first, by enlarging to a panoramic dimension the social depiction; second, by providing coherence to a complex narrative organization; and, third, by focusing on a single character as the centre of events, who receives veracity in his movement from animal drives to intellect, from immorality to morality, self-knowledge, and eventually inner-change.

Influenced by neoclassical realism, foundationalism and essentialism, and by its principles of reason, rationalism, order, common sense, clarity, credibility, experience, and applicability as the grounds for knowledge and discovery, eighteenth-century picaresque fiction passes through a process of thematic transformation involving respect of the genre, faithfulness to fact, a more detailed observation of the social context, a deeper perception of the social perspectives and values, and, consequently, keeping satirical attitude alive, a deeper reflection on contemporary social situations.

The innovation is more important, however, with regard to character representation strategies, the picaro/picara losing his/her flat characteristic and becoming more complex as an individual, acquiring the inner perspectives of existence. Gradually, the rogue loses also the static feature to become subject to a real development based on change, in particular of inner perspectives, in order to acquire, this way, a dynamic personality. In the case of the eighteenthcentury English picaresque novels, these changes are assisted and strengthened by a strong moral vision and didactic purpose, as in Moll Flanders and Tom Jones.

Along with the insight into the character's private and spiritual universe, prefiguring the nineteenth-century realist novel, in general, and the Bildungsroman, in particular, the eighteenth-century picaresque narrative becomes more socially involved, displays more social and moral attitudes, the character tends more towards economic individualism, which, along with the effects of romanticism, determine the picaresque tradition to fall into decline. Decline, but not complete disappearance from the literary scene; it would be present, revived, reshaped and adapted to other settings and circumstances, and the examples are numerous, to mention just Conrad's Lucky Jim, or the fiction of the Angry Young Men, or the more experimental Angela Carter's Nights at the Circus, or, in the literature of the United States, Mark Twain's The 
Golban, P. (2017). An Attempt to Establish a Bildungsroman Development History: Nurturing The Rise of a Subgenre From Ancient Beginnings to Romanticism. Humanitas, 5(10), 111-141

Adventures of Huckleberry Finn, J. D. Salinger's The Catcher in the Rye, and Joseph Heller's Catch-22.

For us, many elements of the picaresque literary system pass into a new one in order to form - together with the elements provided by romanticism, the eighteenth-century English novel, and Goethe - the Bildungsroman literary system, or pattern, whose elements are centred on the principle, or element, of identity formation.

\section{The Rise of the English Novel, Goethe, and the Rise of the Pattern}

In the general eighteenth-century European literary background, the literary work representing the birth of the novel of formation, or the Bildungsroman, is Goethe's Wilhelm Meisters Lehrjahre, the founding work of the subgenre, which occurred as a consequence of the German writer having introduced and established, concerning the plot and character representation strategies, Bildung, or the theme of formation as a literary concern in the novel against the readymade protagonists previously rendered in fiction. The Bildung, that is, formation, emergence, or becoming of the hero's character increasingly mirrored the emergence (social, economic, political, and ideational) of the world around him, which means that Goethe constructed, just as Rabelais did earlier, "an image of man growing in national-historical time" (Bakhtin, "The Bildungsroman", 1986: 25).

Essentially a romantic work, by others yet labelled a "hybrid realism" that fuses realism with individualism, Goethe's text influenced the nineteenth-century English authors of the Bildungsroman. In the novel, the development of Wilhelm as a romantic el picaro is rendered as twofold, comprising emotional and artistic experiences, whereas the principle of formation in his case would be reified by the success or failure of his accomplishment as a happily married and successful artist following his "sensitive soul" consciously "striving for selfdevelopment accompanied by a quest for a suitable vocation and role in the community" (Argyle, 2002: 13). Such a thematic element in the literary system of the Bildungsroman persists in most of the Victorian Bildungsromane, as in David Copperfield, and even in later fiction, as in Sons and Lovers and English Music.

Certainly, however, Goethe is far beyond and above such a simple and straight narrative scheme. As in later novels of formation, in Goethe's Bildungsroman the personal experience of the hero - textualized as a process of building his character - is inseparable from time and milieu, and depends upon Wilhelm's "readiness to respond" to both "nature's material offerings" and "nature's spiritual promptings" (Jeffers, 2005: 27). In this way, Goethe is rooted in German idealism but also in the Enlightenment, and his model of identity formation is based on the idea of an organic growth of the individual and on the belief in historical progress and human perfectibility. 
Golban, P. (2017). An Attempt to Establish a Bildungsroman Development History: Nurturing The Rise of a Subgenre From Ancient Beginnings to Romanticism. Humanitas, 5(10), 111-141

Whatever the degree of grounding the self and the individual psychology in the outward and society, Goethe is more concerned with individual experience, the inward, the soul, the inner life that for him has a meaning, and, since this meaning refers to the process leading to the acquiring of moral wisdom as the highest premise of formation, materialised by the "Certificate of Apprenticeship", Goethe is also concerned with the ways in which the meaning of experience is communicated to the reader.

The experience of Wilhelm, in this respect, can be labelled educative or pedagogical, in the spirit of Rousseau, where "apprenticeship" means accomplishment of maturation, both corresponding to the principle of formation of personality and being reified by the acquisition of values such as devotion, wisdom, moral strength, altruism, and so on.

In other words, formation is equalled to maturation and emergence of personality, and represents the outcome of the change (with emphasis on the spiritual, psychological, emotional, and moral rather than on the physical) of personality, thus revealing and supporting Bakhtin's hypothesis that the Bildungsroman creates "the image of man in the process of becoming".

Goethe's Bildungsroman is discussed as originating primarily in the Enlightenment and idealist philosophies, and even in the German adoration of the Renaissance achievement of universal man. Nonetheless, an important part of its mode of narration, perhaps even the general one, reveals a romantic rebellious attitude in that Goethe's novel founds and defines the genre through its rebellious archetypal hero who rejects his bourgeois origins for more aesthetic aspirations (morphing in later incarnations to the ubiquitous life of the mind), only to be subsumed again through recognition by his masters and the love of a good woman, here resembling Byron's form of compromise and the declaration of love as a superior value to the detriment of either rebelliousness or escapism.

Assisted by the educational ideal of Jean-Jacques Rousseau (in Emile) and Friedrich Schiller (in Aesthetic Education), Goethe's romantic formation or Bildung is a humanistic Bildung as well, where individual development concerning the issues of "eros, parental responsibility, and freedom of choice" (Jeffers, 2005: 14) - framed within high moral standards - has a double perspective of accomplishment. First, it is linked to the idea of nurturing, maturation, learning, formation, emergence, and enlightenment of "an individual's many-sided potential - the development of the uomo universale" (Jeffers, 2005: 14). Second, it is the source of perfectibility of humankind, in general, and the moral-didactic aspect of social resonance is another thematic focus that would persist in the system of the Bildungsroman. With regard to aesthetics, the humanist attitude is that a good writer must be a good man, a guide and guardian of morality. 
Golban, P. (2017). An Attempt to Establish a Bildungsroman Development History: Nurturing The Rise of a Subgenre From Ancient Beginnings to Romanticism. Humanitas, 5(10), 111-141

Sustained in Goethe by a sentimental tone accompanied by irony and framed within a lucid and precise narrative movement, the point of view, expressed by the voice of an apparently distant narrator, invites the reader to progress and pursue his/her own Bildung along with the protagonist; and, along with the narrator, to review the process of experience and apprehend, if not create, its meaning. Almost unchanged, this strategy of rendering the development and formation of a mature personality is followed by Carlyle in his own Bildungsroman, Sartor Resartus, but the closest to the spirit of Goethe as a pedagogical author would be Dickens, whose characters David and Pip also pass through educative experiences with strong moral considerations. Dickens would send his message to the reader, however, through the voice of a more deeply involved, omniscient narrator. Dickens would also change Goethe's authorial irony into softer, humour-like types of the comic and add to sentimentalism a good portion of melodrama.

The Victorians would also keep the unity of education and travelling, apprenticeship and journey as major dimensions of the experience of development leading to individual Bildung, or formation. As in Goethe, the chronotope of the road invites the large-scale representation of the world, in the interaction with which the protagonist achieves physical growth, and, above all, spiritual accomplishment, or Bildung, as self-realization, self-culture, and attainment of an individual identity.

In the eighteenth-century English literary background, the literary work that marks explicitly the transition from the picaresque to the Bildungsroman - that is, from mere development to both development and formation of the individual subject - is Tom Jones, perhaps the most complex novel of the period. Tom Jones gives the highest literary expression to the principle of verisimilitude, marking the coming to its end of the process of the rise of the English novel. Fielding's masterpiece, termed "of manners" and "panoramic", and linking the comic with the moral, apart from Moll Flanders and Roderick Random, is the most picaresque of all the eighteenth-century English novels. The picaresque elements are present in a text that keeps intact the picaresque character representation strategies, the episodic structure of the picaresque narrative, the presentation of a world without order, the character involved in many, often unpredictable, and always realistic circumstances and events.

Prefiguring the types of chronotope in a Bildungsroman, in Tom Jones, the chronotope of home equals in matters of thematic consistency that of city life, and both are linked by the equally important chronotope of the road. As in picaresque fiction in general, and as in the future novels of formation, travelling, or wandering, offers the possibility of escape, freedom, adventure, separation from the past, fresh perspectives, but also anonymity, difficulties, misfortune, danger, and especially embarrassing situations and traps of immorality to test the hero's spiritual strength. 
Golban, P. (2017). An Attempt to Establish a Bildungsroman Development History: Nurturing The Rise of a Subgenre From Ancient Beginnings to Romanticism. Humanitas, 5(10), 111-141

In later picaresque novels, as in Tom Jones, diachronically closest to the rise of the Bildungsroman, these, especially negative, aspects of experience, which are placed on the road and not only, constitute formative principles in building a personal identity; eventually, through repentance and reflection, the protagonist is changed, and the new inner perspectives offer a possibility of reward, allow the character to remove his/her picaresque personality and to be granted a social status, a place in the world.

The eighteenth century, as the age of the birth of the Bildungsroman, saw the convergence and, in some ways, the fusion of novel and biography, which manifested itself in the mutual enrichment of the two types of writing and in the gradual dissolution of their stylistic differences. The novel, assuming either an objective biographical or a subjective confessional manner of writing, would include diaries, letters, memoirs, and other documents that support faithfulness to fact and verisimilitude. Biography borrowed, in turn, the psychological insight and description of spiritual experience to enrich the plot and especially to achieve character individualization. In this period, biography becomes a fictional element together with the chronotope of the city and both are positioned as thematic components within the Bildungsroman literary system. As neoclassicism is a urban, metropolitan type of culture, the rise of the English novel includes the city as a chronotope to be found in Victorian and twentiethcentury Bildungsromane.

\section{Final Remarks: The Interrelationship of the Sources}

The rise of the Bildungsroman as a subgenre in English literature in the Victorian Age is thus nurtured by a threefold stream of literary traditions: (1) the picaresque narrative, (2) romanticism, and (3) Goethe's Wilhelm Meisters Lehrjahre. All of them are of equal importance for the establishment of a new fictional pattern, a new literary system in a new, that of the Victorian Britain, literary and cultural background. Of the three sources, the second and the third are, to a greater extent, already vivid in the first English Bildungsroman, which is Carlyle's Sartor Resartus.

To these three sources as points of reference in the study of the Bildungsroman development history, we should add (4) the eighteenth-century rise of the English novel, in general, with its threefold thematic perspective that consists of (a) sentimental outlook, (b) comic mode, and (c) moral didacticism, as revealed in Tom Jones; also, as revealed in other novels, such as Robinson Crusoe, with its expression of certain (d) neoclassical principles. The label "Age of the Novel" given to the eighteenth century points to the fact that in that period the English novel manifested itself as an eruption of long extended narratives representing a phenomenon which is comparable to another which had occurred more than a century earlier: the flourishing of Elizabethan drama.

The four sources of the Bildungsroman thus identified - romantic principles, picaresque elements, thematic aspects of Goethe's and the eighteenth-century 
Golban, P. (2017). An Attempt to Establish a Bildungsroman Development History: Nurturing The Rise of a Subgenre From Ancient Beginnings to Romanticism. Humanitas, 5(10), 111-141

English novel - persist in later Victorian fiction, in general, and in the Bildungsromane, in particular, each to a lesser or greater extent depending on each individual novel. The four sources receive a new, the fifth literary input, this time from within the contemporary cultural and literary context, which is that of (5) realism, following the remarkable contribution of Carlyle with his moment of a threefold literary reception of Goethe's canonical Bildungsroman that became a supreme example and inspired the early British authors of the novel of formation.

The rise of the English novel in the eighteenth century nurtured the rise of the Bildungsroman as a subgenre representative of English fiction by its social focus, moral and didactic concern, and the expression of some of neoclassical principles. By these elements and, by keeping the picaresque tradition, the eighteenth-century English novel equals the contribution of romanticism and Goethe's Wilhelm Meisters Lehrjahre. The emergence of the novel in the eighteenth century relies on the belief in personal and historical progress, and especially on the interest in individual psychology.

Responsible for the foundation of the modern novel is verisimilitude, or the realist element, whose significance stands in serving moral and pedagogical ends. Another more or less strict requirement is "a sign of our freedom" (Eagleton, 2005: 17) - "I am at liberty to make what laws I please therein", declares Fielding about himself in Book 2 of Tom Jones - and the realist novel "emerges at a point where everyday experience begins to seem enthralling in its own right" (Eagleton, 2005: 37).

Equally responsible for the rise of the Bildungsroman in English literature, shaping its thematic components, is the romantic literature of Wordsworth, Coleridge, Shelley, Byron, Scott, and Keats. Among the many works of these writers that should be discussed in relation to the rise of the Victorian novel of formation is Waverly, in its both individual and historical perspective of literary concern. More important is perhaps The Prelude, "the history of a Poet's mind", that could be called Bildungsgedicht, or Lehrgedicht, and viewed as a romantic proto-Bildungsroman in verse form, similar to the novel Tom Jones as another proto-Bildungsroman representing the age of the rise of the English novel in the eighteenth century. The Prelude, a subjective response to the external world, a poem about the transition from external reality to the internalization of the external reality, "enacts an intellectual and spiritual journey in terms of the poet's own experience" and reveals how he "perceived that significance lay not in the simple object in the world of Nature, but un the power of imagination to work upon the impression he retained" (Butler, 1981: 67). Gisela Argyle truly calls Wordsworth's poem "a typical Romantic Bildungsgeschichte (story of Bildung)", as she does with Coleridge's Biographia Literaria, a "quasiBildungsroman", in her words, in which Coleridge attempts "to derive, in the 
Golban, P. (2017). An Attempt to Establish a Bildungsroman Development History: Nurturing The Rise of a Subgenre From Ancient Beginnings to Romanticism. Humanitas, 5(10), 111-141

German manner, principles of literary criticism from philosophical speculation" (2002: 15).

Romanticism changes the concern from the social to the personal, from social accomplishment and security to private, inner well-being with regard to acquiring an identity and the accomplishment of an individual experience. Apart from the concern with the individual, other thematic aspects of the literary system of the Bildungsroman, which have their roots in the English Romantic Movement, would be the emphasis on individuality, individual emotional and psychological states, the concern with the development of a personal consciousness, the concern with the experience of childhood, the concern with nature and the countryside, pantheism, escapism, rebelliousness, and the dualism of existence.

The Victorian writers of the Bildungsroman, in the age of realism covering much of the nineteenth century, would keep these elements, and, in particular, those novelists who, like Thackeray and Dickens, embraced the realist strategies, would also mark a return to social and moral concerns, and thereby gave new thematic and formal perspectives to the way in which the process of development of character as identity formation is rendered.

The romantic elements preserved by the Victorian novel would be, of course, changed and receive different textual representations. For example, concerning childhood and the child's character, in romanticism they are exponents of a paradisiacal, pure, innocent, imaginatively created, in all respects a superior level of existence as an alternative to the harsh and thwarting reality; the childhood experience is the essence of a particular literary myth, a mode of escapism and also an inseparable, forming and initiatory, part for the process of maturation. No matter how transitory, frail and viewed through the lens of nostalgia, romantics declared childhood a "happy season", which is not the case in the realist Bildungsroman, as the representation of the childhood experience in romanticism is "far removed from the realities of daily life in which the novel deals" (Banerjee, 1996: 31). Victorians would keep the importance of childhood in their rendering of the development and formation of an individual personality, but more often in the way in which Erik Erikson views childhood "as a gradual unfolding of the personality through phase-specific psychological crises" (128), which emerge as turning points suggesting at once something negative and something positive, and being determined by various internal conflicts, usually between two elements: for instance, Pip faces the choice of either remaining in the village or beginning his school experience, each of the two perspectives containing positive and negative aspects.

On a more general level, the shift from romanticism to Victorianism in matters of writing the Bildungsroman is the shift from the self-imposed, personal values and choices, as a sign of individuality, to those imposed by society (to hypothesise an opposition of Cain, Manfred and Childe Harold versus David 
Golban, P. (2017). An Attempt to Establish a Bildungsroman Development History: Nurturing The Rise of a Subgenre From Ancient Beginnings to Romanticism. Humanitas, 5(10), 111-141

Copperfield, Pip and Jane Eyre). What in romanticism is a relationship of nonrelationship between the individual and society - rebelliousness and especially the dualism of existence and escapism emerge as a result of the author's attempts, by means of imagination, to create an alternative reality (or rather, a non-reality) to the contemporary social construction of reality - in the period of realism becomes a relationship based on the principles of determinism and interdependence. Now, the success of character formation includes the development and accomplishment on both the inner and the outer level of existence, and those who rebel, or individualize, or keep creating alternatives are marginalized, fail, like Pip, or are viewed as threatening or as different and, as a result, even scapegoated, like Maggie.

Like the previous traditions (picaresque, the eighteenth-century novel, neoclassicism, romanticism, and Goethe) combined to give the Bildungsroman, the elements of the literary system of realism emerge in the aftermath of romanticism into the newly established literary system of the novel of formation (the Bildungsroman) to receive various degrees of thematic and structural representation, depending on the author's adherence to one or another trend or movement, and on his or her extent of concern with and the weight of focus on the individual experience and/or social and moral issues.

Realism is a strong literary presence in the Victorian Age and as such co-exists with a continuation of the romantic tradition and with the more experimental and original avant-garde. Apart from the realist Bildungsroman, the Victorian period contains novels of formation expressing other than social and moral concerns and reflecting other than realist and sociological views. Also, the advancement of female authorship determines the Bildungsroman to focus on women as well and to render their experience of self-assertion as framed in a process of development and formation of an individual personality similar to that of male protagonists, but with necessary changes and nuances of textualization. Realism versus aestheticism, male versus female, individual versus social, spiritual versus material, childhood versus maturity, rustic versus urban, personal achievement versus social success, these and many other thematic aspects offer power and scope, in English literature, to the nineteenthcentury, or Victorian, novel of formation, as well as to the Bildungsroman in the age of modernism, and the postmodern and postmodernist Bildungsroman.

\section{The Flourishing of the Bildungsroman}

The intense flourishing of the Bildungsroman occurs in the nineteenth century in the Victorian Age, but the twentieth-century and contemporary Bildungsromane, with all their complexity and the new thematic and narrative perspectives on individual development and formation in the context of the opposition between modernity and postmodernity and between modernism and postmodernism, also reveal the vitality and continuity of the subgenre. 
Golban, P. (2017). An Attempt to Establish a Bildungsroman Development History: Nurturing The Rise of a Subgenre From Ancient Beginnings to Romanticism. Humanitas, 5(10), 111-141

The main reason for the division of the Bildungsromane into types according to three major periods - Victorian Age, the age of modernism, and the postmodern period - constitutes the different perspectives from which the literature of the Victorian Age, of modernism and of postmodernism consider the representation of individual existence. Prior to these periods - in neoclassicism - reason, rationalism, experiment, order, common sense, social responsibility, and moral principles govern the character representation strategies in the literary works. Against these principles, in particular against neoclassical social concern and its emphasis on reason and ethics, in romanticism the main concern encompasses now personal emotional and psychological states; the individual is inadaptable, superior, solitary, intellectual, separated from community, while the relationships between the individual and society or reality are those of (1) rebelliousness and (2) escapism, the latter usually in the framework of the romantic dualism of existence.

Following, and to a certain degree continuing, the romantic emphasis on individual experience with its personal, spiritual, mainly emotional accomplishment (as in Goethe and later in Sartor Resartus and Marius the Epicurean), the Victorian realists added and emphasised the social, professional, moral and family fulfilment more than the concern with individual subject. In the Victorian Bildungsroman, as in realist fiction in general, the character receives a complex thematic representation. The shift from romanticism to realism is the shift from the individual to the general human, from the subjective to the social, from the human being as master of his or her destiny to a multitude of character types as social units, from the narrow circle of personal existence to the wide social panorama containing many social sectors and character types presented in social interaction. Realism tends to present its characters as being defined by social and economic factors. The keyterms are "determinism", "environment", "heredity", in other words, "la race, le milieu et le moment", as well as "moral didacticism".

In David Copperfield, Dickens maintains alive a romantic perspective in which human personality is highly emphasised and the character is a master of his destiny, independent, and able to fulfil personally in spite of all social interaction and determinism. The determinism of the milieu is strong but not successful; there is no real social influence or effect on the development of personality, and the outcome is the success of the character formation.

In Great Expectations, however, the character is highly individualised but reveals strong bonds with the background: the character is a subjected subject, dependent on his milieu; he is subject to social determinism and as such subject to inner and outer change. Social determinism is strong and successful; society influences and affects in a negative way the development of personality, and hence the failure of character formation. 
Golban, P. (2017). An Attempt to Establish a Bildungsroman Development History: Nurturing The Rise of a Subgenre From Ancient Beginnings to Romanticism. Humanitas, 5(10), 111-141

Thus, as in the latter novel, the Enlightenment reliance on mind and reason and the idea of their inseparability from or perfect match with world and nature are already challenged in the Victorian period. However, this challenge will reveal itself to the highest degree in the twentieth century.

Modernists like Joyce and Woolf focus on individual experience with its personal, spiritual, subjective, emotional and now above all psychological dimension, on abstract manifestations of the mind and on phenomena that make them possible. They keep the social concern to a lesser degree, to show the impossibility of harmony between internal and external factors, hence the character's frustration and alienation. Simply stated, such novels lack the harmony which is often constructed for their protagonists by the traditional Victorian writers of the Bildungsroman. In their attempt to achieve the apoliticization of aesthetics and to defend the high art, modernists like Joyce and Woolf promote the elevation of individual consciousness over social action and interaction as one component of a complex system of binary oppositions including culture versus science and nature, progressive versus degenerate forms and trends in human history, aesthetics versus politics, literary versus non-literary, and highbrow modernist art versus trash, kitsch, degraded mass culture. The personal experience as fictionally treated by the modernists reveals the demise of the integrated individual subject through the expression of the fragmentariness of self; the world too is rendered fragmentary through thematic and narrative organization, such as is achieved by employing the techniques of montage and collage.

The thematic components of the novel of formation are adapted by modernists as well as by postmodernists to suit their various concerns and techniques. The postmodern Bildungsroman depicts the individual as "self", as well as "subject" and "being", occupying another position in language; the result of another conception and another discourse; author and character simultaneously; "subjected" and "ordered" by dominant, legitimizing discourses; or self being socially constructed. In all these cases the accomplishment is problematic. This view of the social construction of the self ignores the evidence for the growth of an individual through the socialization process, since the theory of the socially constructed self "ignores the way the self is constituted by an individual's maintenance of an original, often idiosyncratic narrative of him or herself. This is the key to creativity in the individual" (Butler 58). Therefore, we should speak about two directions in the postmodern Bildungsroman, (1) a postmodernist view of the individual as being, self, subject that is subjected, ordered, dominated, determined, constructed, and so on; and (2) a liberal humanist view of the individual as being, self, subject that displays autonomy and self-sufficiency, that is, a free subject that creates himself or herself on the basis of his or her personal experience. Liberal humanism as a major alternative to postmodernism relies on a set of ideas which takes for granted the autonomy and self-sufficiency of the subject and argues that the human beings are free and 
Golban, P. (2017). An Attempt to Establish a Bildungsroman Development History: Nurturing The Rise of a Subgenre From Ancient Beginnings to Romanticism. Humanitas, 5(10), 111-141

create or form themselves and their self on the basis of their individual experience. The Bildungsroman Never Let Me Go, for instance, raises this problem of identity and refuses it for the character to be autonomous and selfsufficient. Another novel of formation, Midnight's Children, considers both views, but the former is a stronger voice. Nights at the Circus also contains both attitudes, but the latter emerges as dominant at the end. English Music, another postmodern Bildungsroman, argues for the latter, humanist opinion, while also reifying Harold Bloom's accreditation of the canon and individual authority.

\section{Conclusion}

In general, despite particular periods of its production, the Bildungsroman is often labelled the novel of youth, the novel of education, the novel of apprenticeship, the novel of adolescence, the novel of initiation, the coming-ofage novel, and the life-novel. The anglicised form the "apprenticeship novel" is highly used, yet the "novel of development" and the "novel of formation" are the most frequently used terms, often taken as synonyms. However, from a diachronic perspective on the novelistic genre concerning character representation strategies, development is different from Bildung or "formation", and the latter, in our opinion, is the more accurate term to be applied to novels designated as Bildungsromane.

In this respect, our assumption is that until Goethe's novel, the main principles in the texts dealing with life experiences are the "development" of character and the "change" of his/her outer condition, as in various picaresque novels (characters may be round but not dynamic), whereas with and since the German writer to the present, the development is a process both biological and intellectual, spatial and temporal, internal and external (characters are both round and dynamic). Bildung or "formation" of personality - since it represents the expected outcome of the development and is reified by the change of inner condition as well - becomes the governing principle in the thematic arrangement that focuses on the process of growth and maturation, allowing the use of the label "Bildungsroman" and its existence as a still strong literary tradition and a systemic type of novel.

Our study focuses on the Bildungsroman development history, that is, on those periods, movements, genres, and various literary experiences that occurred before the nineteenth century and influenced the rise and flourishing of the Bildungsroman in Victorian fiction. In Britain the Bildungsroman became one of the most favourite literary models primarily for Victorian realists because its fictional pattern, consisting of the literary treatment of the process of development and formation of a character in relation to society, offers the necessary extension and complexity to the literary concern with individual experience and the social background.

Apart from the Victorian Bildungsroman, both realist and non-realist, there are various twentieth-century realist, modernist and postmodern novels of 
Golban, P. (2017). An Attempt to Establish a Bildungsroman Development History: Nurturing The Rise of a Subgenre From Ancient Beginnings to Romanticism. Humanitas, 5(10), 111-141

formation, which reveals the persistency and the productivity of this fictional subgenre. As to make a list, the most representative Bildungsromane of the Victorian Age would be Sartor Resartus (1836) by Thomas Carlyle, Ernest Maltravers (1837) and Alice (1838) by Edward Bulwer-Lytton, Jane Eyre (1847) by Charlotte Brontë, Wuthering Heights (1847) by Emily Brontë, The History of Pendennis (1848-1850) by William Makepeace Thackeray, David Copperfield (1849-1850) and Great Expectations (1860-1861) by Charles Dickens, Aurora Leigh: A Poem in Nine Books (1856) by Elizabeth Barrett Browning, The Ordeal of Richard Feverel (1859) by George Meredith, The Mill on the Floss (1860) by George Eliot, Marius the Epicurean (1885) by Walter Pater, Jude the Obscure (1896) by Thomas Hardy, What Maisie Knew (1897) by Henry James, The Way of All Flesh (1903) by Samuel Butler. The age of modernism or late modern period contains such Bildungsromane as Herbert George Wells's Tono-Bungay (1909), David Herbert Lawrence's Sons and Lovers (1913), E. M. Forster's Maurice (1913-1914, pub. 1971), William Somerset Maugham's Of Human Bondage (1915), James Joyce's A Portrait of the Artist as a Young Man (1916), and Virginia Woolf's Jacob's Room (1922). The postmodern and contemporary period would promote as novels of formation Salman Rushdie's Midnight's Children (1981), Kamala Markandaya's Pleasure City (Shalimar, 1982/1983), Angela Carter's Nights at the Circus (1984), Jeanette Winterson's Oranges Are Not the Only Fruit (1985), Anita Brookner's A Closed Eye (1991), Peter Ackroyd's English Music (1992), Zadie Smith's White Teeth (2000), Monica Ali's Brick Lane (2003), Kazuo Ishiguro's Never Let Me Go (2005), David Mitchell's Black Swan Green (2006), and other works.

The aim of our approach is to point out and disclose the existence of a history of development of the Bildungsroman, whereas the Victorian, late modern and postmodern texts generally designated and accepted as Bildungsromane might represent the concern and content of other, independent and certainly much more extended, studies.

\section{References}

Abrams, M. H. (1970). English Romanticism: The Spirit of the Age. In H. Bloom (Ed.), Romanticism and Consciousness: Essays in Criticism (pp. 91-119). New York: W. W. Norton and Company.

Alter, R. (1965). Rogue's Progress: Studies in the Picaresque Novel. Cambridge: Harvard University Press.

Argyle, G. (2002). Germany as Model and Monster: Allusions in English Fiction, 1830s-1930s. Montreal: McGill-Queen's University Press.

Auerbach, E. (2000). Mimesis: Reprezentarea realitatii in literatura occidentala. Iasi: Polirom. 
Golban, P. (2017). An Attempt to Establish a Bildungsroman Development History:

Nurturing The Rise of a Subgenre From Ancient Beginnings to Romanticism. Humanitas, 5(10), 111-141

Bahti, T. (2001). Literary criticism and the history of ideas. In C. Knellwolf and C. Norris (Eds.), The Cambridge History of Literary Criticism, Volume 9: Twentieth Century Historical, Philosophical and Psychological Perspectives (pp. 31-42). Cambridge: Cambridge University Press.

Bakhtin, M. M. (1981). Forms of Time and of the Chronotope in the Novel. In Michael Holquist (Ed.), The Dialogic Imagination: Four Essays (pp. 84-258). Austin: University of Texas Press.

(1986). The Bildungsroman and Its Significance in the History of Realism: Toward a Historical Typology of the Novel. In Caryl Emerson and Michael Holquist (Eds.), Speech Genres and Other Late Essays (pp. 10-59). Austin: University of Texas Press.

Banerjee, J. (1996). Through the Northern Gate: Childhood and Growing Up in British Fiction, 1719-1901. Bern: Peter Lang AG.

Bjornson, R. (1977). The Picaresque Hero in European Fiction. Wisconsin: The University of Wisconsin Press.

Butler, M. (1981). Romantics, Rebels and Reactionaries: English Literature and its Background 1760-1830. Oxford: Oxford University Press.

Chase, C. (1993). Romanticism. London: Longman.

Eagleton, T. (2005). The English Novel: An Introduction. Oxford: Blackwell Publishing.

Frye, N. (1990). Anatomy of Criticism: Four Essays. London: Penguin Books.

Guillén, C. (1971). Toward a Definition of the Picaresque. In Literature as System: Essays Toward the Theory of Literary History (pp. 71-110). Princeton: Princeton University Press.

(1987). The Anatomies of Roguery. The Origins and the Nature of Picaresque Literature. New York: Garland.

Jeffers, Thomas L. (2005). Apprenticeships: The Bildungsroman from Goethe to Santayana. New York: Palgrave Macmillan.

Moretti, F. (2000). The Way of the World: The Bildungsroman in European Culture. London: Verso.

Robert, M. (1983). Romanul inceputurilor si inceputurile romanului. Bucuresti: Editura Univers.

Roznoveanu, M. (1983). Civilizatia romanului. Bucuresti: Editura Albatros.

Wellek, R. (1963). Concepts of Criticism. London: Yale University Press. 